\title{
Metodologia para estudos da qualidade das águas subterrâneas e sua aplicação para caracterização hidrogeoquímica do Aquífero Guarani
}

\author{
Heraldo Cavalheiro Navajas Sampaio Campos \\ Geólogo - Doutor em Ciências - Centro de Apoio \\ Operacional à Execução - CAEx - Ministério Público \\ do Estado de São Paulo \\ heraldocampos@mpsp.mp.br
}

\begin{abstract}
METHODOLOGY FOR STUDIES OF GROUNDWATER QUALITY AND ITS APPLICATION FOR HYDROGEOCHEMICAL CHARACTERIZATION OF THE GUARANI AQUIFER. The Guarani Aquifer is one of the largest reservoirs of groundwater in the world and represents a strategic reserve for the four countries where it occurs in South America - Argentina, Brazil, Paraguay and Uruguay. The municipality of Ribeirão Preto, located in the northeastern region of the state of São Paulo, with a population of over 600,000 inhabitants, is supplied entirely by waters of the aquifer. In this city and region it occurs intensive use of groundwater; a large number of operating wells already show problems of interference among each other. At the same time, one can notice the increased risk of contamination of groundwater by increasing the fonts installed on places where the aquifer is at the surface (primarily related to pesticide use for agriculture), which are highly vulnerable. This paper presents a methodology for investigation of data quality groundwater chemistry and its application to the hydrogeochemical characterization of the Guarani Aquifer, within the territory of Ribeirão Preto and region. Citation: Campos H.C.N.S. 2013. Metodologia para estudos da qualidade das águas subterrâneas e sua aplicação para a caracterização hidrogeoquímica do Aquífero Guarani. Terræ Didatica, 9(2):114-131. < http://www.ige.unicamp.br/terraedidatica/> .
\end{abstract}

KEYWORDS: Methodology, quality, groundwater, Guarani Aquifer

RESUMO O Aquifero Guarani é um dos maiores reservatórios de águas subterrâneas do planeta e representa uma reserva estratégica para os quatro países da América do Sul - Argentina, Brasil, Paraguai e Uruguai - onde ele ocorre. O município de Ribeirão Preto, localizado na região Nordeste do Estado de São Paulo, com uma população de mais 600 mil habitantes, é suprido inteiramente pelas águas do aquifero. Nesse município e região vem ocorrendo o uso intensivo de água subterrânea e uma numerosa quantidade de poços em atividade já evidenciam problemas de interferência entre eles. Ao mesmo tempo, percebe-se o aumento do risco de contaminação das águas subterrâneas por incremento de fontes instaladas sobre as partes aflorantes do aquífero (principalmente as relacionadas ao uso de agrotóxicos na agricultura), que são de alta vulnerabilidade. Este trabalho apresenta metodologia para investigação de dados de qualidade química de águas subterrâneas e sua aplicação para a caracterização hidrogeoquímica do Aquífero Guarani, no âmbito do território ribeirão-pretano e região.

PALAVRAS CHAVE: Metodologias, qualidade, águas subterrâneas, Aquífero Guarani. 


\section{Introdução}

O Aquífero Guarani é um dos maiores reservatórios de águas subterrâneas do planeta e representa uma reserva estratégica para os quatro países da América do Sul onde ele ocorre: Argentina, Brasil, Paraguai e Uruguai. O município de Ribeirão Preto, localizado na região Nordeste do Estado de São Paulo, com população de mais 600 mil habitantes, é suprido inteiramente pelas águas do aquífero.

Regionalmente, o Aquífero Guarani está intercalado entre as camadas permianas do Grupo Passa Dois e os derrames basálticos cretácicos da Formação Serra Geral. É constituído de arenitos eólicos e fluviais bem selecionados, com espessura média de 300 metros, atingindo profundidades de até 1.500 $\mathrm{m}$. Trata-se de aquífero livre apenas nas bordas da Bacia do Paraná e confinado em $90 \%$ de sua extensão. Graças as suas excelentes características hidrogeológicas constitui-se na principal reserva de água subterrânea de uma das mais importantes províncias hidrogeológicas do brasileiras, a Paraná.

O Brasil, por dispor de $70 \%$ da área do Aquífero Guarani em seu território, vem acumulando ao longo dos últimos 30 anos muita informação seja pelos levantamentos regionais realizados, como por exemplo, no Estado de São Paulo, ou mesmo pelas pesquisas acadêmicas desenvolvidas pelas universidades. No município de Ribeirão Preto e região vem ocorrendo o uso intensivo de água subterrânea e uma numerosa quantidade de poços em atividade já evidenciam problemas de interferência entre eles. Ao mesmo tempo, percebe-se o aumento do risco de contaminação das águas subterrâneas por incremento de fontes instaladas sobre as partes aflorantes do aquífero (principalmente as relacionadas ao uso de agrotóxicos na agricultura), que são de alta vulnerabilidade.

Neste trabalho é apresentada uma metodologia para investigação de dados de qualidade química de águas subterrâneas e sua aplicação para caracterização hidrogeoquímica do Aquífero Guarani, no âmbito do território ribeirão-pretano e região.

\section{Metodologia para estudos da qualidade das águas subterrâneas}

\section{Coleta de Informações}

Quando não existem antecedentes de dados químicos de águas subterrâneas em uma determinada área de estudo regional, é necessário obter uma base de informações primárias visando à caracterização hidrogeoquímica dos aquíferos ou reservatórios subterrâneos investigados.

Após a coleta de dados, sua interpretação e integração possibilitarão levantar alguns aspectos de interesse sobre os aquíferos investigados como:

- entendimento da relação rocha/água;

- compreensão da evolução da composição química natural das águas subterrâneas com o fluxo nos reservatórios;

- estabelecimento da divisão dos aquíferos em zonas hidrogeoquímicas como ferramenta na caracterização de unidades hidrogeológicas;

- determinação de anomalias hidrogeoquímicas e sua provável origem.

Assim, um primeiro passo é a seleção das informações dos poços, para individualizar os aquíferos que se baseia na existência de perfil geológico confiável e a sua distribuição espacial em área, de forma homogênea, evitando adensamento ou vazios. O segundo passo é a elaboração do programa de medidas de campo e de amostragem das águas dos poços selecionados. Como geralmente na escala de investigação regional as águas extraídas dos poços são destinadas a diferentes usos (abastecimento público, irrigação e indústria), as amostras são coletadas diretamente da boca dos poços uma vez que os mesmos possuem equipamento de bombeamento instalado. Dessa maneira, no campo, no instante da coleta, são feitas as medidas de $\mathrm{pH}$, temperatura ambiente, temperatura da água, condutividade elétrica e alcalinidade.

Um exemplo desse tipo de metodologia foi aplicado pelo Departamento de Águas e Energia Elétrica (DAEE) do Estado de São Paulo entre 1974 e 1981, para o então denominado "Estudos de Águas Subterrâneas". Mais recentemente, no ano de 2006, o "Projeto de Proteção Ambiental e Desenvolvimento Sustentável do Sistema Aquífero Guarani”, sob os auspícios da Organização dos Estados Americanos (OEA) usou metodologia semelhante.

A sequência de fotos da figura 1 mostra uma coleta feita no dia 15/08/2006, as $10 \mathrm{~h} 00$ da manhã, para o poço de abastecimento público ${ }^{\circ} 100 / 23$ do DAERP (Departamento de Água e Esgoto de Ribeirão Preto) no Bairro Monte Alegre, próximo ao Campus da USP e do Hospital das Clínicas em Ribeirão Preto (SP). O poço amostrado atravessou 173 metros de basaltos, 183 metros de arenitos (Aquífero Guarani) e 5 metros de diabásios, 
com profundidade da bomba a $246 \mathrm{~m}$ e vazão de $230 \mathrm{~m}^{3} / \mathrm{h}$. As medidas in situ foram a temperatura ambiente $\left(23^{\circ} \mathrm{C}\right)$, temperatura da água na boca do poço $\left(27^{\circ} \mathrm{C}\right), \mathrm{pH}(6,39)$ e condutividade elétrica (93 micromho/cm).

A coleta de informações para o estudo hidrogeoquímico permite compreender a evolução da composição das águas subterrâneas ao longo do seu trajeto de percolação nas rochas, relacionando a evolução às direções e sentidos de fluxo com o tempo de permanência das águas nos aquíferos. No entanto, a ocorrência de fenômenos modificadores da composição química das águas no interior dos

A

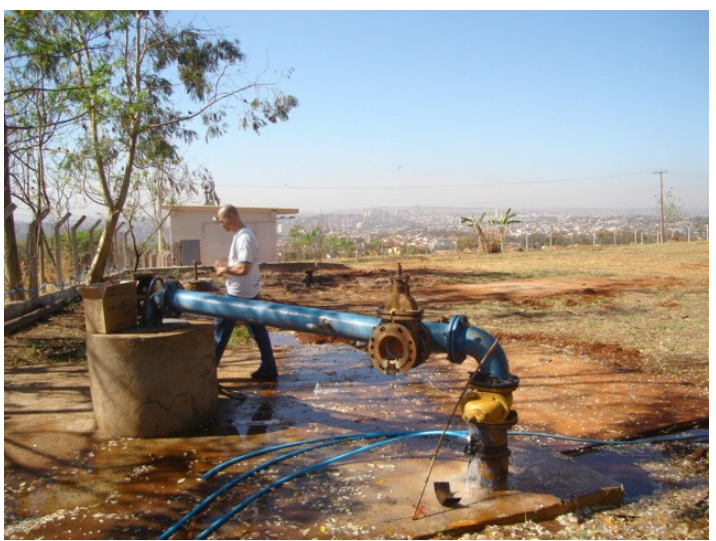

B

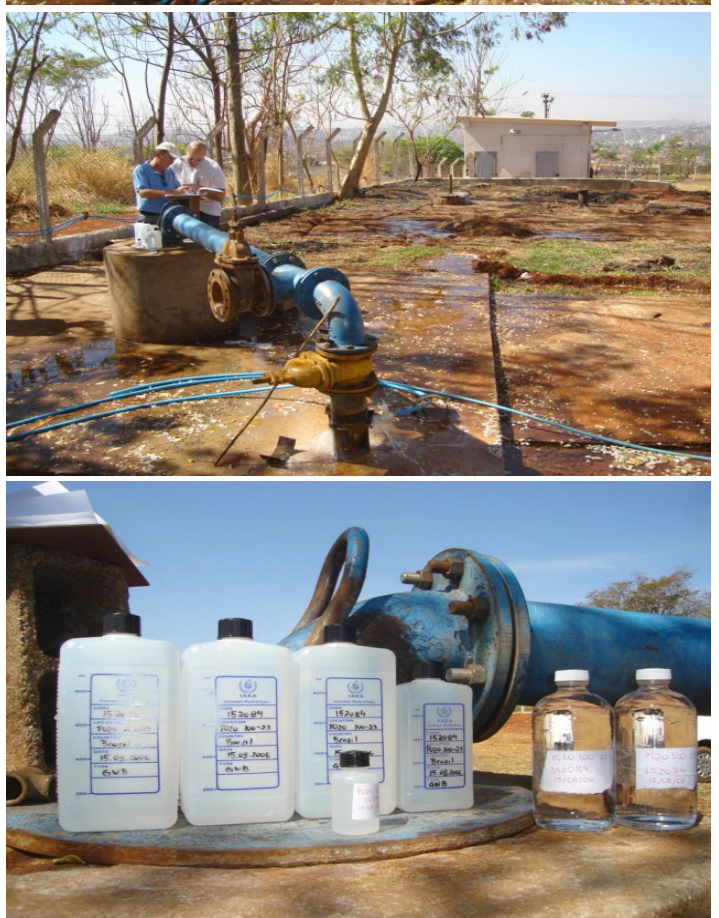

Figura 1. Poço de abastecimento público n 100/23 do DAERP (A). Poço $n^{\circ}$ 100/23 do DAERP, em outro ângulo; ao fundo, poço de monitoramento (B). Frascos com coleta de amostras de água do poço para análises bacteriológica, físico-química e isotópica em laboratório (C) reservatórios subterrâneos, como trocas de base, reduções de sulfatos e ferro, óxido-reduções, concentrações, dissoluções e precipitações, limita a caracterização da história evolutiva do caminho das águas subterrâneas. Por essa razão, vem sendo amplamente aplicada, em associação a dados das informações hidrogeoquímicas, a metodologia dos estudos de isótopos ambientais como, por exemplo, ${ }^{18} \mathrm{O},{ }^{2} \mathrm{H},{ }^{13} \mathrm{C} \mathrm{e}{ }^{14} \mathrm{C}$. A determinação destes isótopos ambientais permite investigar a origem ou a história das águas, podendo-se identificar a localização, o período e o processo de recarga das águas de um aquífero.

$\mathrm{Na}$ área de estudo, os trabalhos de Gallo (1977) e Gallo e Sinelli (1980) foram os primeiros a compor estudo integrado, hidrogeoquímico e isotópico, do Aquífero Guarani na região de Ribeirão Preto. Outro trabalho dessa natureza e de forma pioneira na área de ocorrência do Aquífero Guarani no Estado de São Paulo foi o de Silva (1983), que utilizou técnicas hidrogeoquímicas e isotópicas para investigar regionalmente os mecanismos da evolução da composição química das águas subterrâneas.

\section{Definição dos parâmetros}

A definição e o rol dos parâmetros a serem amostrados nos estudos de reconhecimento hidrogeológico e hidrogeoquímico regionais são lastreados, principalmente, nas características físico-químicas das análises das águas subterrâneas, com destaque especial para a identificação dos cátions e dos ânions maiores presentes.

O Departamento de Águas e Energia Elétrica (DAEE) para os "Estudos de Águas Subterrâneas" no período entre 1974 e 1981, utilizando-se dos laboratórios da Cetesb (Companhia Ambiental do Estado de São Paulo), adotou o procedimento descrito a seguir para a coleta e o processamento das amostras de águas subterrâneas.

As amostras para análises físico-químicas são coletadas em frascos de polietileno, novos e descartáveis, refrigerados a $4^{\circ} \mathrm{C}$, com gelo, em caixa de isopor, sendo 3 litros sem preservativos para análise de alcalinidade, cloreto, fluoreto, sulfato, sílica, condutividade elétrica, resíduos a $105^{\circ} \mathrm{C}$ e $180^{\circ} \mathrm{C}$ e carbonato.

Um frasco com 1,5 litros de água coletada recebe 2,5 $\mathrm{ml}$ de $\mathrm{HNO}_{3}$ para determinação de dureza, ferro total, cálcio, magnésio, boro, sódio e potássio. Outro frasco, de $250 \mathrm{ml}$ de água amos- 
trada deve ter $2,5 \mathrm{ml}$ de $\mathrm{H}_{2} \mathrm{SO}_{4}$ concentrado para exame de nitrato.

Uma referência para esse tipo de cuidado na coleta e na preservação das amostras de águas pode ser encontrado no "Guia Técnico de Coleta de Amostras da Cetesb".

Os métodos de análises químicas aplicados em laboratórios geralmente seguem o Standard Methods for the Examination of Water and Wastewater da American Public Health Association dos Estados Unidos. Para determinação dos parâmetros físico-químicos das águas subterrâneas, à temperatura de $25^{\circ} \mathrm{C}$, são:

- $\mathrm{pH}$ - método potenciométrico

- condutividade elétrica - condutivímetro de eletrodo

- resíduo a $105^{\circ} \mathrm{C}$ e $180^{\circ} \mathrm{C}$ - ensaio gravimétrico

- $\mathrm{Ca}^{2+}, \mathrm{Mg}^{2+}$ e dureza total - ensaio titulométrico EDTA

- $\mathrm{Na}^{+}$e $\mathrm{K}^{+}-$absorção atômica

- $\mathrm{HCO}^{3-}$ e $\mathrm{CO}^{32-}$ - titulação potenciométrica

- $\mathrm{Cl}^{-}$- ensaio titulométrico nitrato-mercúrio

- $\mathrm{SO}^{42-}$ - ensaio turbimétrico cloreto de bário

- $\mathrm{NO}^{3-}$ - auto-analyser com sulfalinamida

- $\mathrm{Fe}^{2+}$ - auto-analyser com orto-fenatrolina

- $\mathrm{F}^{-}$- ensaio colorimétrico SPANDS

- $\mathrm{SiO}^{2}$ - ensaio colorimétrico com molibdato de amônia

\section{Monitoramento de campo}

A análise de dados obtidos para estudos regionais de investigação hidrogeológica e hidrogeoquímica podem envolver uma sequência de trabalhos que pode privilegiar áreas menores ou sub-bacias representativas de aquíferos individualizados. Assim, além de serem amostrados novamente os mesmos poços de determinada área para que se possam comparar com uma campanha de amostragem anterior, com base nos parâmetros físico-químicos já mencionados, as perfurações e amostragens especiais que permitam a coleta em determinada zona aquífera podem propiciar o acompanhamento e a evolução das modificações químicas das águas tanto na lateral como na vertical de determinado trecho.

\section{Padrões de referência}

A abundância ou escassez de água é o primeiro fator que condiciona sua utilização, de modo que uma água de qualidade ruim, mas abundante, pode tornar-se mais importante do que uma água boa com quantidades insuficientes. Os limites de concentração química fixados ou sugeridos pelos órgãos governamentais, geralmente, representam um ajuste entre a qualidade da água desejada e a qualidade de água disponível em quantidades suficientes para atender a demanda.

Dessa maneira, os padrões da adequação das águas para os diversos fins normalmente adotados encerram certa flexibilidade, uma vez que nem todos os componentes presentes têm a mesma importância e, por outro lado, torna-se às vezes impossível conseguir, em uma determinada região, águas que atendam plenamente às recomendações das normas vigentes.

No Brasil, a Portaria do Ministério da Saúde no 2914 de 12/12/2011 que "dispõe sobre os procedimentos de controle e de vigilância da qualidade da água para consumo humano e seu padrão de potabilidade", é a norma vigente.

A verificação da adequação das águas subterrâneas para a irrigação pode ser feita com base no diagrama e nos padrões de salinidade do "Laboratório de Salinidade de Riverside, Departamento de Águas dos Estados Unidos" e no exame de qualidade das águas subterrâneas para fins industriais (Logan 1965).

\section{Processamento dos dados}

A sistemática de trabalho para este tipo de levantamento de dados já foi adotada em outros estudos do autor (Campos 1987, 1993, 2000a, 2000 b e 2003) e foi adequada para os objetivos pretendidos. A seleção das informações dos poços, visando individualizar os aquíferos na área de estudo, foi baseada na existência de perfil geológico confiável e a distribuição espacial em área, de forma homogênea, evitando adensamento ou vazios. Para o processamento automático dos dados em microcomputador, alguns softwares usados comumente na cartografia hidrogeológica e hidrogeoquímica serviram de suporte para as ações propostas neste projeto, principalmente os que geram mapas de contorno como o SURFER (Surface Mapping System) e o ArcGIS.

\section{Fatores que controlam a qualidade da água subterrânea}

O caminho das águas na crosta terrestre é bastante complexo. Por causa da energia solar uma molécula de água, por um número infinitamente grande de estímulos, pode ser evaporada do ocea- 
no e a ele retornar precipitada pelas chuvas. Pode, também, cair sobre os continentes infiltrando-se solo abaixo, ser absorvida pelas plantas ou retornar indiretamente aos mares pelos rios e ribeirões.

Por onde a água passa, produz modificações. Pode dissolver os minerais das rochas e arrastar seus componentes bem distantes para a deposição. Pode formar rios, lagos e oceanos acumulando um volume considerável de espécies aquáticas. Pode transbordar em áreas de inundação e causar prejuízos econômicos em áreas urbanas. Pode se acumular no subsolo e constituir os aquíferos ou reservatórios de águas subterrâneas.

Em áreas continentais muito afastadas da costa, como a porção central do Planalto Ocidental do Estado de São Paulo, que dista cerca de $600 \mathrm{~km}$ da Costa Atlântica, as águas de chuva são em geral muito pouco salinizadas e os conteúdos em cálcio, magnésio, potássio e sódio é muito baixo.

As águas de recarga dos reservatórios subterrâneos procedem das precipitações ou dos corpos d'água superficiais ou, ainda, de outros aquíferos com os quais mantenham conexão hidráulica. Assim, o aporte de sais aos aquíferos depende, inicialmente, da composição química das águas de recarga e, em seguida, da interação química entre essas águas e o meio aquífero. Portanto, sua evolução química passa a ser influenciada diretamente pelas rochas atravessadas.

Por sua vez, os fatores que determinam a composição e a concentração química das águas dos rios são mais variáveis. Entre estes fatores se encontram as dissoluções de materiais do solo e das rochas, as adições de sais provenientes das restituições das águas subterrâneas e os elementos químicos distribuídos pelo consumo doméstico, plantações e despejos industriais.

\section{A relação das águas subterrâneas com contextos geológicos}

Como foi visto as águas fazem parte de um ciclo. Esse ciclo deve ser mais bem compreendido, tanto do ponto de vista quantitativo como qualitativo (química das águas) para, consequentemente, ser mais bem gerenciado.

O recente trabalho de Gastmans et al. (2012) mostra a relação das águas subterrâneas do Aquífero Guarani com os contextos geológicos em escala regional. Em termos geológicos, os autores definem o Aquífero Guarani:
(...) como um sistema aquífero constituído por um conjunto de rochas sedimentares mesozóicas continentais, essencialmente siliciclásticas, em continuidade física (ou aparente continuidade), com alta capacidade de armazenar e transmitir água, limitado em sua base por uma extensa discordância regional permo-eotriásica, e no topo pelo inicio dos derrames basálticos do Cretáceo Inferior (Gastmans et al. 2012).

Sobre as condições de fluxo das águas subterrâneas no Aquífero Guarani os mesmos autores descrevem que:

(...) o sentido preferencial é N-S, com recargas associadas principalmente nas áreas de afloramento localizadas na faixa este do aquífero, e descargas regionais na faixa oeste dos afloramentos, são claramente condicionadas pelas estruturas geológicas associadas a evolução tectônica das bacias do Paraná e Chacoparanense. Enquanto que o levantamento das bordas este e norte da bacia, ocorrido durante a ruptura do Gondwana, condiciona as principais áreas de recarga, as estruturas regionais internas, como o Arco de Ponta Grossa e a Dorsal Assunção-Rio Grande, condicionam o fluxo. O Arco de Ponta Grossa atua como una barreira ao fluxo proveniente do norte e a Dorsal Assunção-Rio Grande divide o SAG em dois compartimentos distintos, podendo adicionalmente funcionar como um alto que condiciona uma ampla área de descarga regional (Gastmans et al. 2012).

Em escala regional, a evolução hidrogeoquímica das águas subterrâneas do Aquífero Guarani também mostra relação com o marco geológico,

(...) seja pelas reações que surgem da interação rocha/ água, que imprimem as principais características hidroquímicas a essa água, ou pelo condicionamento do fluxo, responsável pela mistura das águas provenientes dos aquíferos subjacentes ao SAG, que são controladas pelos principais traços estruturais da bacia (Gastmans et al. 2012).

Sobre a relação das águas subterrâneas com os contextos geológicos, em escala local, o trabalho de Paula e Silva et al. (2008) descreve que o arcabouço litoestratigráfico do Sistema Aquífero Guarani, em Ribeirão Preto:

(...) é composto pelas formações Pirambóia e Botucatu que, individualmente, compõem unidades aqüíferas homônimas. Este pacote rochoso assenta-se sobre substrato impermeável, formado por rochas pelíticas da Formação Corumbataí, cujo compor- 
tamento hidrodinâmico regional é de um aqüiclude, e é recoberto extensivamente por rochas basálticas da Formação Serra Geral, ausentes apenas em parte das porções leste e nordeste da área urbana, onde estão expostos sedimentos da Formação Botucatu (Paula e Silva et al. 2008).

Segundo os autores a subdivisão em termos de hidrofácies do Aquífero Guarani no município de Ribeirão Preto é a seguinte:

O "Aqüífero Pirambóia" é composto por três hidrofácies; as hidrofácies $\mathrm{A}$, inferior, e C, superior, apresentam características de permoporosidade reduzida, em virtude de maior conteúdo de argila; a hidrofácies $\mathrm{B}$, mediana e em geral mais espessa, é composta por arenitos finos a grossos, em parte conglomeráticos, com elevada permoporosidade. O "Aqüífero Botucatu", formado unicamente pela hidrofácies D, é composto por arenitos finos a médios, limpos, de elevada permoporosidade (Paula e Silva et al. 2008).

Dessa maneira, o contexto geológico do Aquífero Guarani propicia excelentes características hidrogeológicas para o reservatório, constituindo-se numa das principais reservas de água subterrânea da maior província hidrogeológica brasileira, a Paraná. Nesta reserva existem dezenas de poços com profundidades superiores aos 1.000 metros e cujas vazões variam de 300 a $600 \mathrm{~m}^{3} / \mathrm{h}$. Na região Centro-Oeste do Estado de São Paulo o número de poços e a vazão explotada (extraída) por hora do aquífero é assim distribuída: área aflorante com 200 poços $\left(6.000 \mathrm{~m}^{3} / \mathrm{h}\right)$, área de médio confinamento com 700 poços $\left(105.000 \mathrm{~m}^{3} / \mathrm{h}\right)$ e área confinada com 100 poços $\left(30.000 \mathrm{~m}^{3} / \mathrm{h}\right)$.

O Aquífero Guarani ocorre na região Oeste do

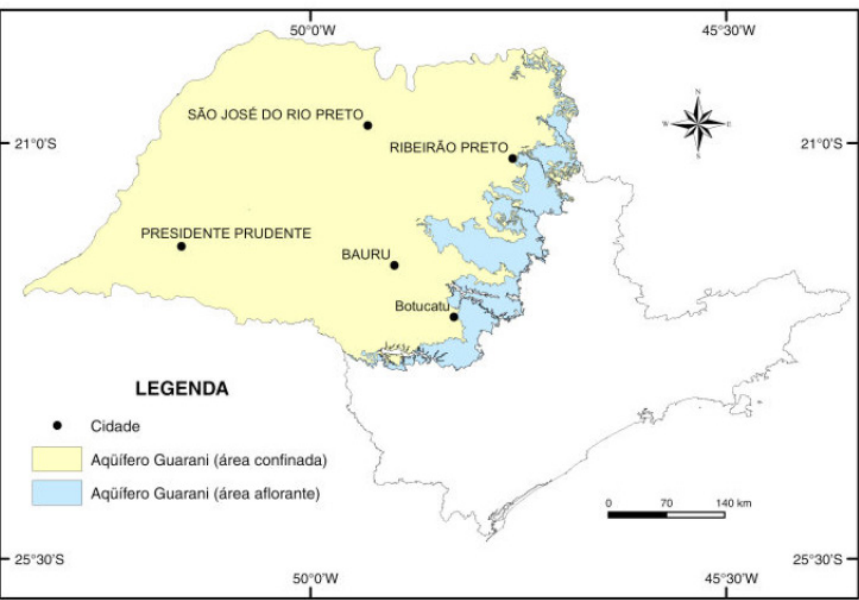

Figura 2. Localização do Aquífero Guarani na região Centro-Oeste do Estado de São Paulo segundo DAEE et al. (2005)

áreas confinadas as temperaturas variam entre $22 \mathrm{e}$ $58,7^{\circ} \mathrm{C}$, o pH entre 6,3 e 9,8 e a salinidade entre 50 e $500 \mathrm{mg} / 1$. Os tipos químicos predominantes em aproximadamente $80 \%$ do reservatório são os das águas bicarbonatada cálcica e bicarbonatada sódica seguida da sulfatada-cloretada sódica.

Em geral, se observa um aumento da temperatura no sentido sudeste-noroeste (Estado de São Paulo), coincidindo com a direção de fluxo. Os valores mais elevados são encontrados próximo do extremo oeste (superior a $60^{\circ} \mathrm{C}$ ), embora também podem ocorrer temperaturas relativamente altas na borda norte e no extremo noroeste (superiores a 45 e $50^{\circ} \mathrm{C}$, respectivamente).

A distribuição espacial da salinidade e das fácies hidroquímicas do Aquífero Guarani na região Centro-Oeste do Estado de São Paulo (Fig. 3), mostra que as zonas próximas da área de recarga apresentam as salinidades mais baixas (inferiores a $200 \mathrm{mg} / \mathrm{l}$ ), uma vez que as mais altas (maiores que Estado de São Paulo (Fig. 2), ocupando cerca de $76 \%$ de seu território. Nesta região, as águas subterrâneas desse reservatório abastecem cidades importantes como Ribeirão Preto, São José do Rio Preto, Presidente Prudente, Marília e Araçatuba.

O Aquífero Guarani na sua área de comportamento livre, as águas apresentam temperaturas compreendidas entre 22 e $27^{\circ} \mathrm{C}, \mathrm{pH}$ entre 5,4 e 9,2 e salinidade inferior a $50 \mathrm{mg} / \mathrm{l}$. Nesta área, o tipo químico predominante é o da água bicarbonatada cálcica seguida da bicarbonatada cálcico-magnesiana. Nas

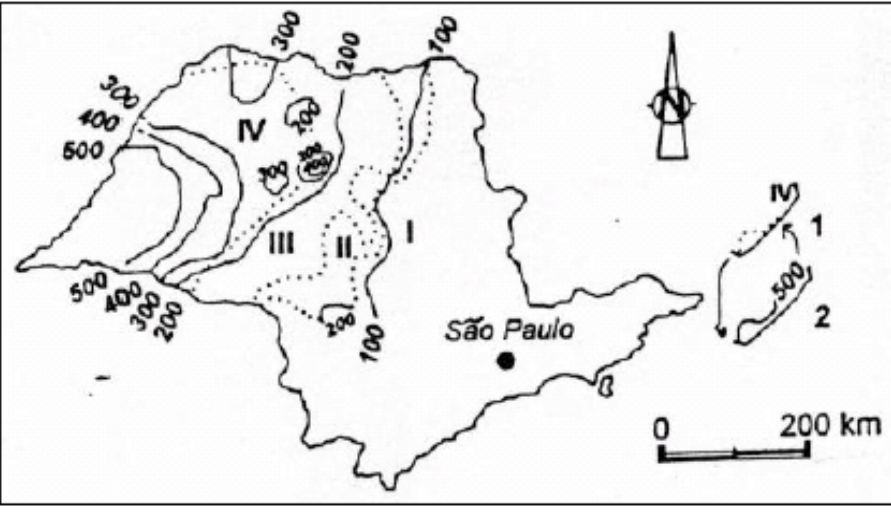

Figura 3. Distribuição espacial da salinidade e das fácies hidroquímicas do Aquífero Guarani na região Centro-Oeste do Estado de São Paulo (Campos e Cerón-Garcia 1998) 
$500 \mathrm{mg} / \mathrm{l}$ ) encontram-se, em geral, no extremo Oeste, coincidindo com a direção de fluxo E-W.

Assim, pode-se observar que as fácies hidroquímicas variam no sentido do fluxo e subdividem-se da porção Leste (livre) até a porção Oeste (confinado) do aquífero, em quatro tipos essenciais: bicarbonatada magnesiana e cálcico-magnesiana (I), bicarbonatada cálcica e cálcico-magnesiana (II), bicarbonatada sódica (III) e, finalmente, sulfatadacloretada sódica (IV).

Em território paulista existe uma tendência regional de aumento das idades das águas do aquífero no sentido Sudoeste a partir da zona de afloramento e o aumento gradual da salinidade das águas está intimamente relacionado com o seu tempo de residência. A região

Sudoeste do Estado de São Paulo, para onde converge a resultante geral do fluxo subterrâneo do aquífero, apresenta águas mais mineralizadas e mais antigas, com idades superiores aos 18.000 anos.

\section{Modelo hidrogeológico conceitual do Aquífero Guarani na região de Ribeirão Preto}

Com a finalidade de obter uma melhor compreensão do sistema de fluxo da água subterrânea do Aquífero Guarani no município de Ribeirão Preto e região, foi desenvolvido um modelo hidrogeológico conceitual preliminar (FIPAI 2009), que se baseou nos dados do trabalho do modelo numérico de Cavicchia (2007) e da análise litofaciológica das formações Pirambóia e Botucatu apresentada por Massoli (2007), para o município de Ribeirão Preto. O estudo abrange uma área de 2.000 $\mathrm{km}^{2}$, tendo como principais limites o Rio Pardo a Norte; Ribeirão da Onça e Ribeirão do Pântano a Sul; Rio Pardo e Ribeirão da Prata a Leste; Córrego do Tamboril e divisor de águas superficiais a Oeste. Na área estão contidos parcial ou integralmente os municípios de Cravinhos, Dumont, Ribeirão Preto, São Simão, Serra Azul, Serrana e Sertãozinho.
A partir desses estudos, foi possível elaborar um modelo (Fig. 4), integrando os dados existentes na área do município de Ribeirão Preto (ver recorte R1, numa visada frontal, mostrando a subsuperfície desta área). Assim, considera-se o topo do Aquífero Guarani (superfície de contato entre o topo da Formação Botucatu e da Formação Serra Geral), a sua superfície potenciométrica e as cotas topográficas do topo, em superfície, coincidindo com as rochas que compõe esses dois reservatórios, ou seja, os arenitos e os basaltos.

Mesmo sabendo-se de antemão da importância da Formação Pirambóia, subjacente à Formação Botucatu, e das partes mais profundas do Aquífero Guarani, que possuem um papel passivo no fluxo subterrâneo (Aquitardo Passa Dois), esses dois componentes ainda estão sem representação nesse modelo preliminar. Aqui, também, são reconhecidos a importância e o papel estrutural dos sills e diques de diabásio, mas, por medida simplificadora, ainda não foram considerados na primeira aproximação nas áreas mais próximas do município de Ribeirão Preto.

No modelo conceitual, supõe-se que o reservatório esteja recoberto na maior parte da área de estudo, ao Oeste, pelo Aquífero Serra Geral e que, dependendo do arranjo das fraturas verticais e subverticais dos basaltos, associado às cargas potenciométricas do Aquífero Guarani, o fluxo de água pode ser ascendente ou descendente.

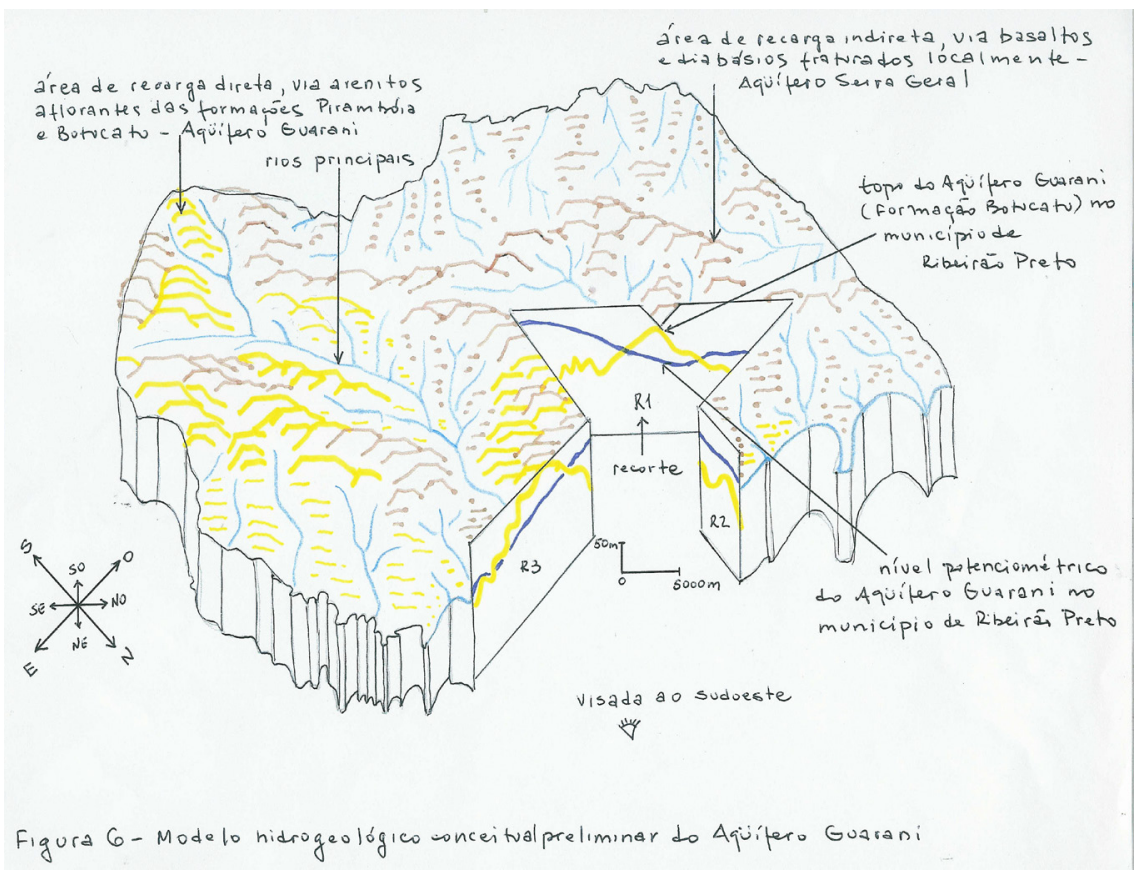

Figura 4. Modelo hidrogeológico conceitual preliminar do Aquífero Guarani para a área de estudo, elaborado pelo autor durante o projeto da FIPAI (2009). 
As cargas potenciométricas podem encontrar-se abaixo do topo do aquífero, fortemente influenciadas pela atividade antrópica ao longo de décadas, como na zona de superexplotação do reservatório no município de Ribeirão Preto (R1) que, por causa desse impacto negativo, geraram medidas de disciplinamento e controle, como será visto mais adiante. Entretanto, as cargas potenciométricas podem situar-se acima desse topo, como em áreas confinadas pelos basaltos do Aquífero Serra Geral (ver recorte R2 na região NW da área), cujas espessuras de cobertura são maiores e, consequentemente, com menor intensidade de explotação, como nas proximidades do Rio Pardo. Nesses setores, caso ocorram lineamentos estruturais (fraturas) que perpassem os dois reservatórios, o fluxo de água subterrânea pode ser ascendente (área de descarga localizada).

De um modo geral, no setor R3 do modelo proposto (Nordeste da área de estudo), no qual vão predominar as áreas de recarga direta, via os arenitos aflorantes das formações Pirambóia e Botucatu, a carga potenciométrica do Aquífero Guarani coloca os níveis de água desse reservatório abaixo da superfície do terreno e deve prevalecer o fluxo descendente de água em quase toda sua extensão (cerca de 1/3 da área de estudo).

Com relação à circulação de água e sentido de fluxo regional no pacote de arenitos que constituem o Aquífero Guarani, as águas de infiltração das chuvas na região entram diretamente pela porção Sudoeste do modelo proposto e caminham para Nordeste, acompanhando o sentido de drenagem principal dos rios da região, até o Rio Pardo.

\section{Distribuição espacial dos teores salinos e dos íons maiores}

No início dos anos 1990, os resultados das análises químicas do DAEE (1974) foram processados pelo Sistema de Informações Químicas de Águas Subterrâneas-SIQUIM (Campos 1993, Souza e Campos 1993) e retomados no presente estudo (123 análises). Os dados mais recentes gerados pelo PSAG (2008b) correspondem a 26 análises. Em geral, as águas de circulação regional, como as que percolam o Aquífero Guarani, tendem a ir aumentando sua mineralização até saturar-se com os diferentes íons. Por causa do processo, a água subterrânea pode ter composição diferente da rocha pela qual circula à medida que se afasta do local da infiltração.

Desse modo, em função dos dados existentes, os cátions e os ânions maiores presentes nas águas do Aquífero Guarani e o conteúdo do teor salino, expressos em $\mathrm{mg} / \mathrm{l}$, foram os parâmetros utilizados para observação das mudanças e da evolução hidrogeoquímica.

O teor salino das águas dos aquíferos está representado na Figura 5, que mostra que os teores salinos mais baixos, até $100 \mathrm{mg} / \mathrm{l}$, correspondem aos poços que captam água do Aquífero Guarani localizados em áreas de afloramento, não confinadas, mais a leste da área de estudo.

Muito embora existam poucos dados distribuídos, os valores de teor salino tendem a aumentar (acima de $180 \mathrm{~m} / \mathrm{l}$ ) para o Oeste, em área de maior espessamento de rochas basálticas e de início de confinamento do Aquífero Guarani. A temperatura dessas águas acompanha essa tendência de incremento podendo atingir valores de $29^{\circ} \mathrm{C}$, como é mostrado na Figura 6.

Com relação aos ânions maiores analisados, observa-se que os teores de bicarbonato nas águas subterrâneas na área de estudo são em geral muito baixos, com os valores mais altos atingindo cerca

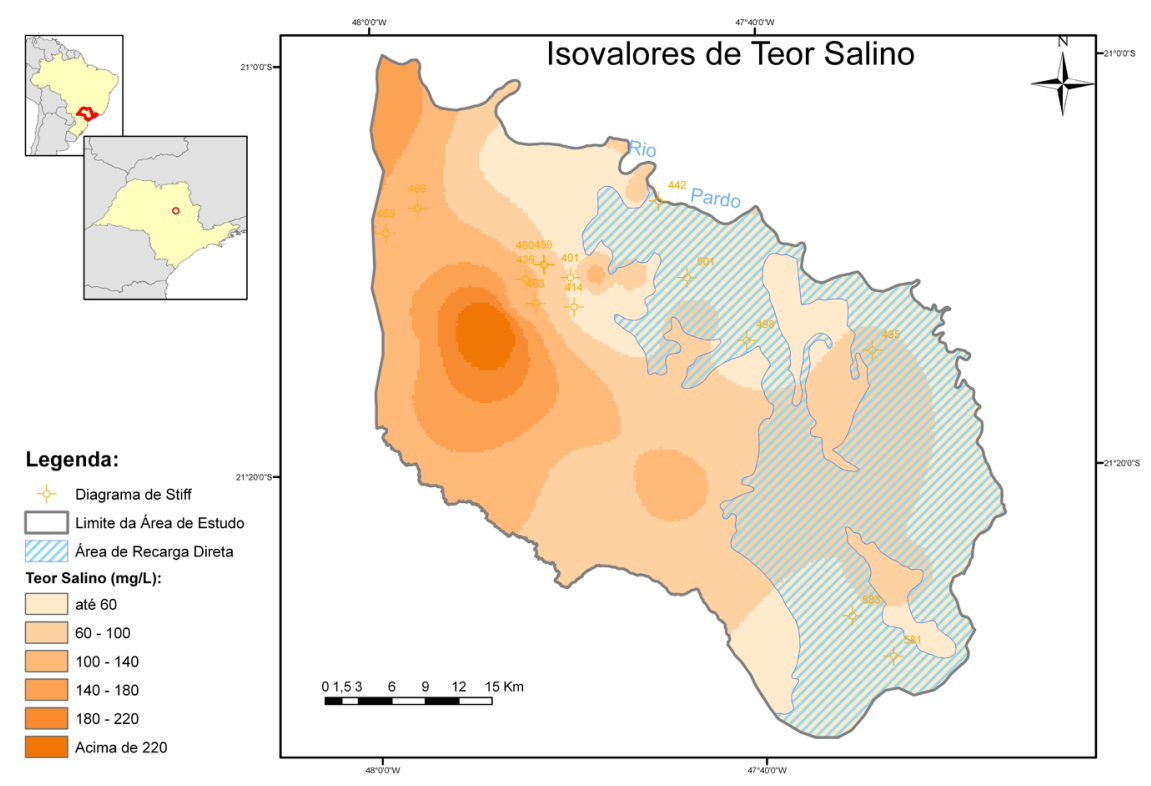

Figura 5. Mapa de isovalores de teor salino em $\mathrm{mg} / \mathrm{l}$ (Resíduo Seco a $180^{\circ} \mathrm{C}$ ) e poços amostrados, a partir dos dados do DAEE (1974). 
de $100 \mathrm{mg} / \mathrm{l}$ a oeste (Fig. 7). Os valores de sulfatos detectados são muito baixos (a maioria dos valores inferiores a 1,6 $\mathrm{mg} / \mathrm{l})$ e o pequeno número de pontos analisados (20) não possibilita boa regionalização do parâmetro para efeito de interpretação.

Apesar de os conteúdos em cloretos serem também baixos, inferiores muitas vezes a $2 \mathrm{mg} / \mathrm{l}$ (Fig. 8), parece haver um tendência de enriquecimento desse ânion para a parte central da área, na região do município de Ribeirão Preto. A origem do ânion cloro pode estar relacionada à precipitação meteórica e/ ou dissolução das micas (sericita e biotita), presentes em pequenas quantidades nas formações Botucatu e Pirambóia, além de cloritas como minerais secundários dos basaltos (Silva 1983).

Para o comportamento dos cátions, observa-se que na maior parte da área, os valores de cálcio estão na faixa de 5 a 10 mg/l (Fig. 9), relacionados provavelmente aos setores de exposição em superfície das rochas da Formação Botucatu e de rochas basálticas da Formação Serra Geral, com pouca espessura, situados ao Leste. Um incremento de cálcio é percebido no sentido Noroeste da área, onde os teores passam de $20 \mathrm{mg} / \mathrm{l}$.

O comportamento do íon magnésio parece ser diferente em área, conforme mostra a Figura 10. A sua distribuição atinge valores superiores a $4 \mathrm{mg} / \mathrm{l}$ ao Sul, com desenho concêntrico, em área nitidamente de afloramento de basaltos, o que sugere a interferência desse tipo de rocha quando da captação das águas dos poços para justificar o aparecimento desse íon.

A distribuição do íon sódio em área (Fig. 11) apresenta valores muito baixos, predominando os teores em torno dos $2 \mathrm{mg} / \mathrm{l}$, mas com suave tendência de aumento para oeste da área de estudo, com valores da ordem de $4 \mathrm{mg} / \mathrm{l}$.

No que se refere ao grau de acidez das águas subterrâneas dos reservatórios estudados, a Figura 12 mostra que os valores de $\mathrm{pH}$ evidenciam águas

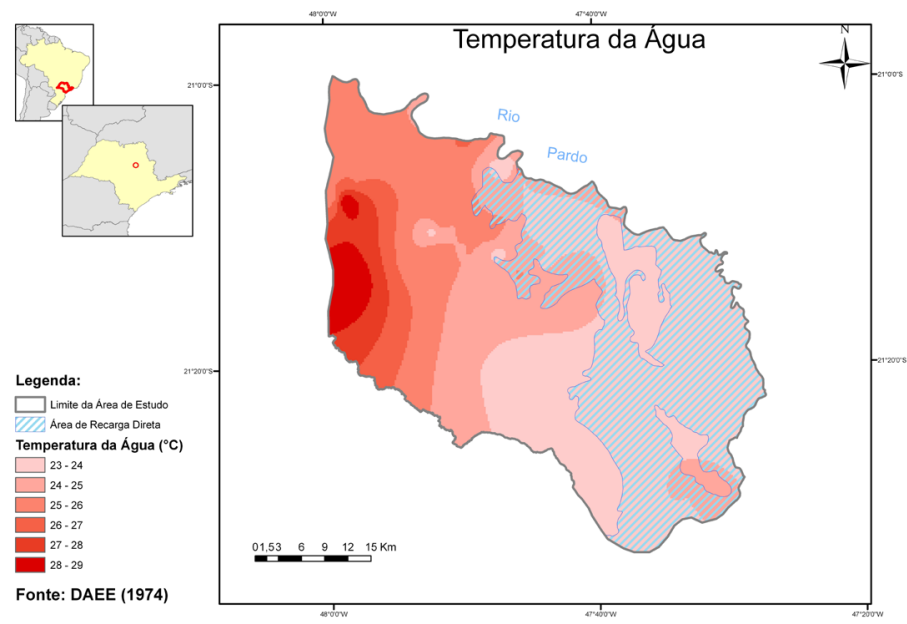

Figura 6. Mapa de isovalores de temperatura em ${ }^{\circ} \mathrm{C}$ e poços amostrados, a partir dos dados do DAEE (1974).

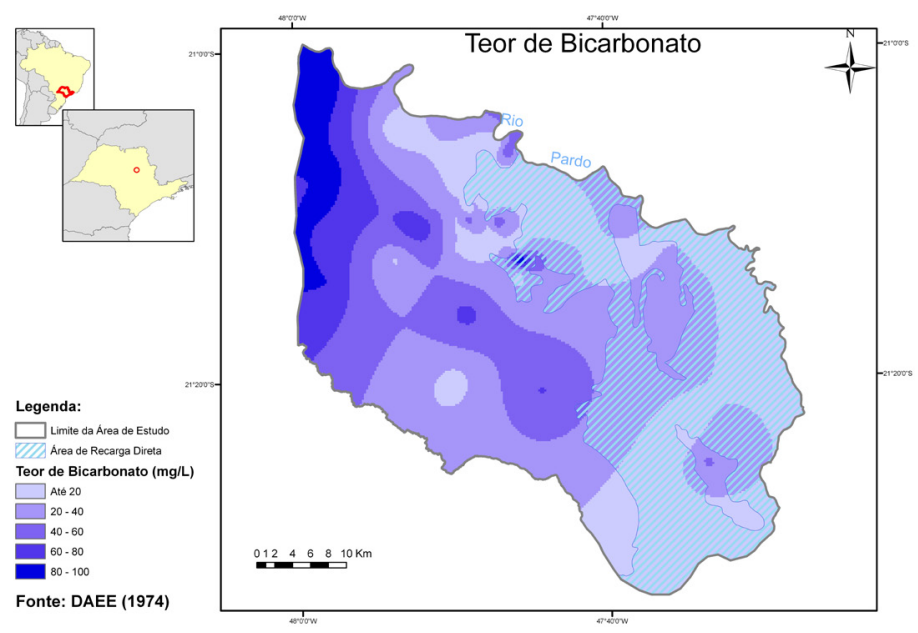

Figura 7. Mapa de isovalores do teor em bicarbonato em $\mathrm{mg} / \mathrm{l}$ e poços amostrados, a partir dos dados do DAEE (1974).

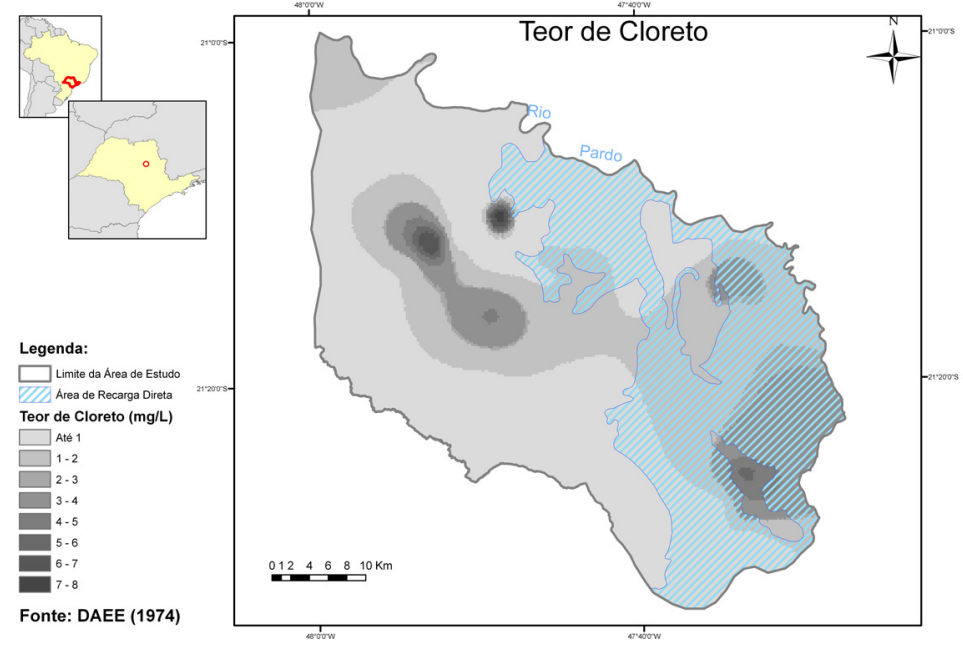

Figura 8. Mapa de isovalores do teor em cloreto em $\mathrm{mg} / \mathrm{l}$ e poços amostrados, a partir dos dados do DAEE (1974). 


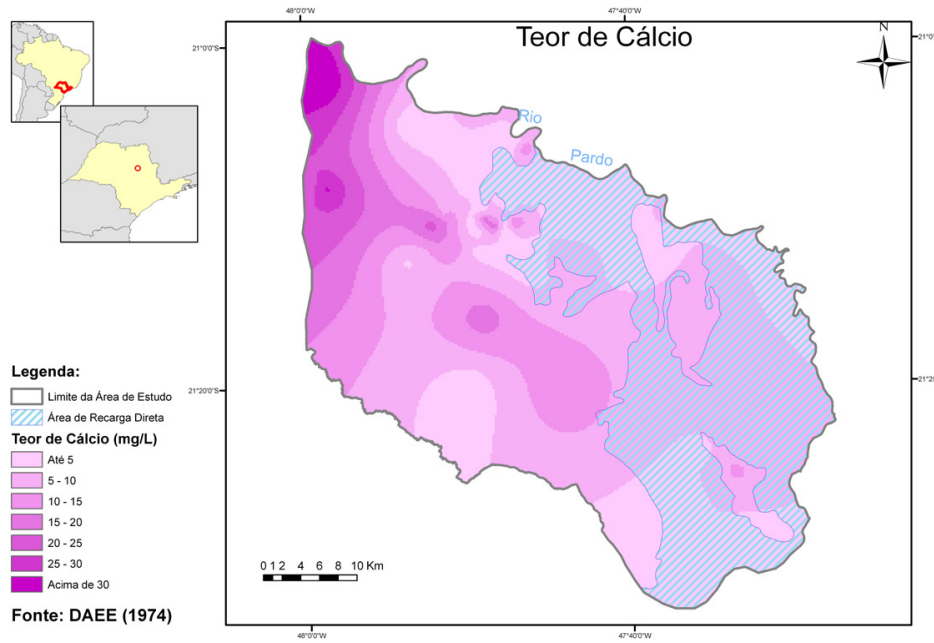

Figura 9. Mapa de isovalores do teor de cálcio em $\mathrm{mg} / \mathrm{l}$ e poços amostrados, a partir dos dados do DAEE (1974).

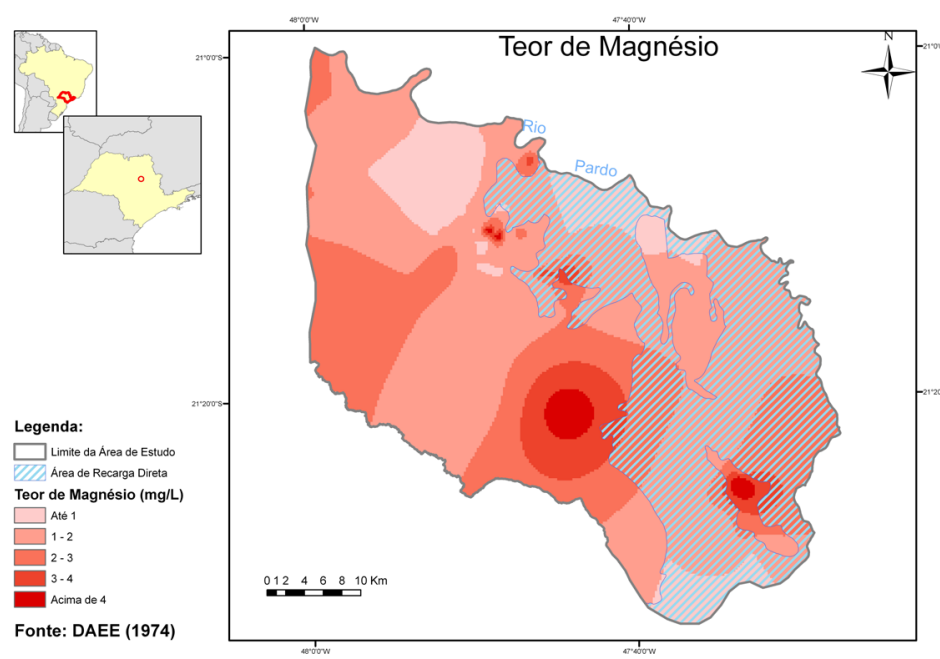

Figura 10. Mapa de isovalores do teor de magnésio em $\mathrm{mg} / \mathrm{l}$ e poços amostrados, a partir dos dados do DAEE (1974).

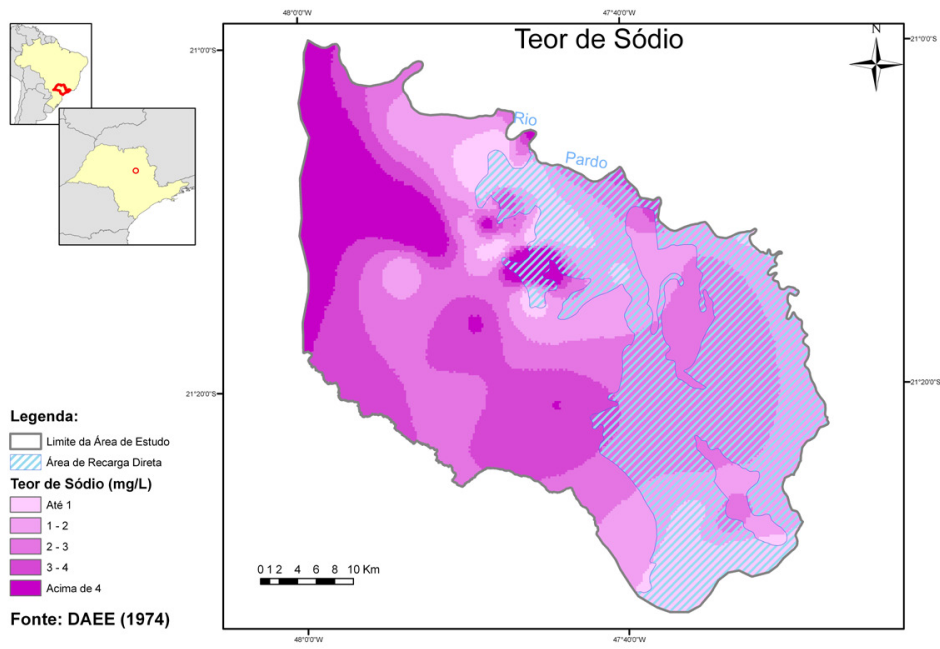

Figura 11. Mapa de isovalores do teor em sódio em mg/l e poços amostrados, a partir dos dados do DAEE (1974). levemente ácidas na porção Leste da área estudada, passando a neutras na parte mais central até atingir um caráter de águas ligeiramente básicas para o Oeste.

Em termos de evolução hidrogeoquímica, os dados até aqui analisados permitem dizer que as zonas próximas da área de recarga (porção Leste da área estudada) apresentam as águas subterrâneas com salinidades e temperaturas mais baixas, $\mathrm{pH}$ ligeiramente ácido, com um ligeiro aumento para Oeste, coincidindo com o sentido de fluxo.

As fácies hidroquímicas, representadas pela variação dos teores principalmente de bicarbonato, cloreto, cálcio e sódio, mostram enriquecimento destes íons com o aumento da profundidade dos poços e, por consequência, com os setores mais confinados do Aquífero Guarani para Leste da área.

\section{A importância relativa das águas subterrâneas}

Os padrões e parâmetros que servem de base para estabelecer a potabilidade da água para consumo humano e sua adequação para irrigação e fins industriais variam de um país para outro. Esses padrões parecem, muitas vezes, mais influenciados pelas características químicas da água disponível do que pelo efeito sobre o sistema orgânico do homem ou pelo tipo de cultivo ou indústria de determinada região. Entretanto, a abundância ou a escassez é o primeiro fator que condiciona a sua utilização. Assim, uma água de qualidade medíocre, mas abundante, pode tornar-se mais desejada que uma água de boa qualidade, porém, em quantidade insuficiente.

Os limites de concentração química fixados ou sugeridos pelos órgãos governamentais representam, geralmente, um ajuste entre a quali- 


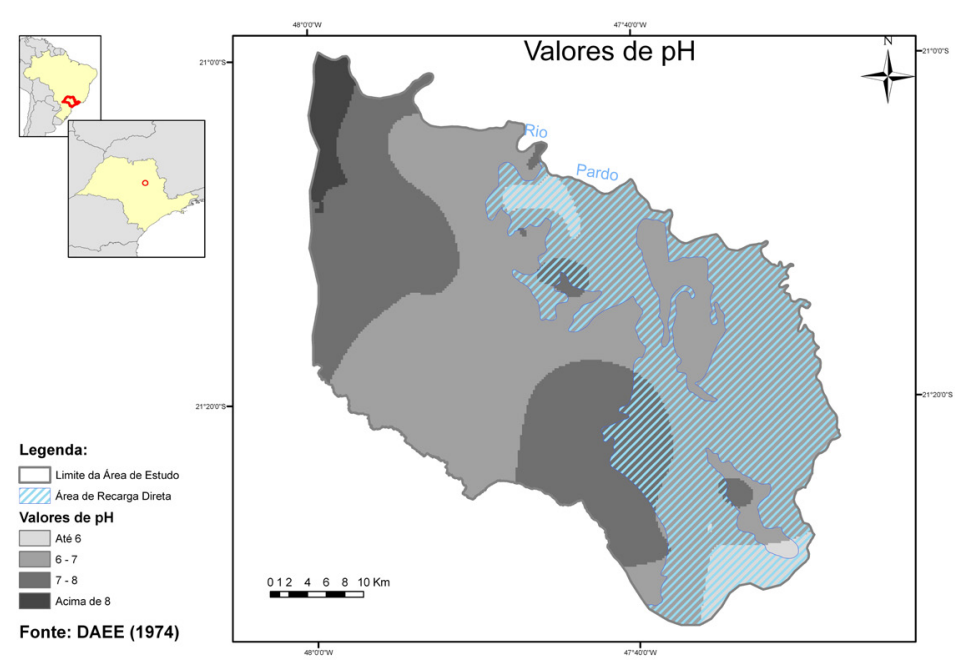

Figura 12. Mapa de isovalores de $\mathrm{pH}$ e poços amostrados, a partir dos dados do DAEE (1974).

dade desejada, a qualidade disponível e as quantidades suficientes para fazer frente às demandas. Deste modo, os padrões de adequação para os diversos fins encerram certa flexibilidade, visto que nem todos os componentes têm a mesma importância.

Por outro lado, às vezes torna-se impossível conseguir, em uma determinada região, águas que atendam plenamente às recomendações das normas vigentes.

As águas subterrâneas dos aquíferos do Estado de São Paulo são, em geral, de boa qualidade, não apresentando restrições para o consumo humano e animal, para a irrigação e uso industrial.

O município de Ribeirão Preto, que é abastecido $100 \%$ pelas águas do Aquífero Guarani, se inscreve nesse contexto. Todavia, existe uma variação dos teores de nitratos que não tem relação direta com as características das rochas que compõem os diferentes reservatórios subterrâneos.

Assim, se os teores de nitratos das águas dos poços excedem o limite recomendado, quase sempre é por causa de poços contaminados pela atividade humana. Isso acontece pela proximidade de fossas negras ou mesmo de estábulos na zona rural, além da possibilidade de existir contaminação por meio de fertilizantes agrícolas. Esses indícios podem indicar a precariedade construtiva dos poços, como ausência de tubo de boca com cimentação e tampa protetora, falta de laje de proteção e de perímetro de proteção sanitária.

Os teores detectados de nitrato nas águas subterrâneas, com base nos dados dos trabalhos mais recentes de Invernizzi (2001) - valor máximo de 6,29 mg/l, Bonotto (2006) - valor máximo de 3,1 mg/1 e PSAG (2008b) - valor máximo de 4,07 mg/l, revelam que esse parâmetro está dentro do valor máximo permissível $(10 \mathrm{mg} / \mathrm{l})$, segundo a Portaria do Ministério da Saúde $\mathrm{n}^{\mathrm{o}}$ 2914 de 12/12/2011.

A presença de flúor na água destinada ao consumo humano pode ser benéfica ou não, dependendo da sua concentração. Nos países onde a prática da fluoretação artificial é bem administrada, os resultados demonstram que é possível reduzir a cárie dentária no período de crescimento da população infantil. Em concentrações mais elevadas, porém, o flúor é responsável pelo surgimento da fluorose dental. As crianças afetadas pela fluorose podem apresentar manchas de descoloração, provocadas pela escavação do esmalte que, eventualmente, levam ao abalo e à perda dos dentes afetados.

Uma das hipóteses para explicar a origem deste elemento em teores excessivos (acima de 1,2 mg/l F) é sua ascensão para as águas subterrâneas através dos condicionantes estruturais. No Estado de São Paulo as anomalias de fluoreto aparecem distribuídas localmente por todos os aquíferos, mas algumas áreas mais expressivas podem estar associadas às proximidades dos alinhamentos estruturais na Bacia do Paraná, as zonas sismogênicas (zonas geradoras de sismos), as anomalias geotermais na crosta e a tendência estrutural nordeste do embasamento cristalino (Campos 1993). A distribuição dos teores de fluoreto em área é mostrada na Figura 13. Sua origem pode estar relacionada ao condicionamento estrutural e/ou a composição litológica do Aquífero Guarani. Esses teores em área são muito baixos, para um valor máximo permissível de $1,5 \mathrm{mg} / 1$.

Além desse fato, praticamente todas as águas subterrâneas contêm um pouco de ferro e sua química no meio aquífero é complexa. Elas podem adquirir o ferro pelo contato com o revestimento do poço, o conjunto moto-bomba e as tubulações. Quanto mais corrosiva é em sua composição, mais dissolve o ferro das superfícies com as quais estabelece contato, devendo os projetos de equipamentos industriais e de captação profunda levar em conta a adequada seleção de materiais, a fim de minimizar este processo.

A água subterrânea captada de um poço tubular contendo ferro em quantidade apreciável pode se tornar límpida e incolor logo após o bombeamento. 


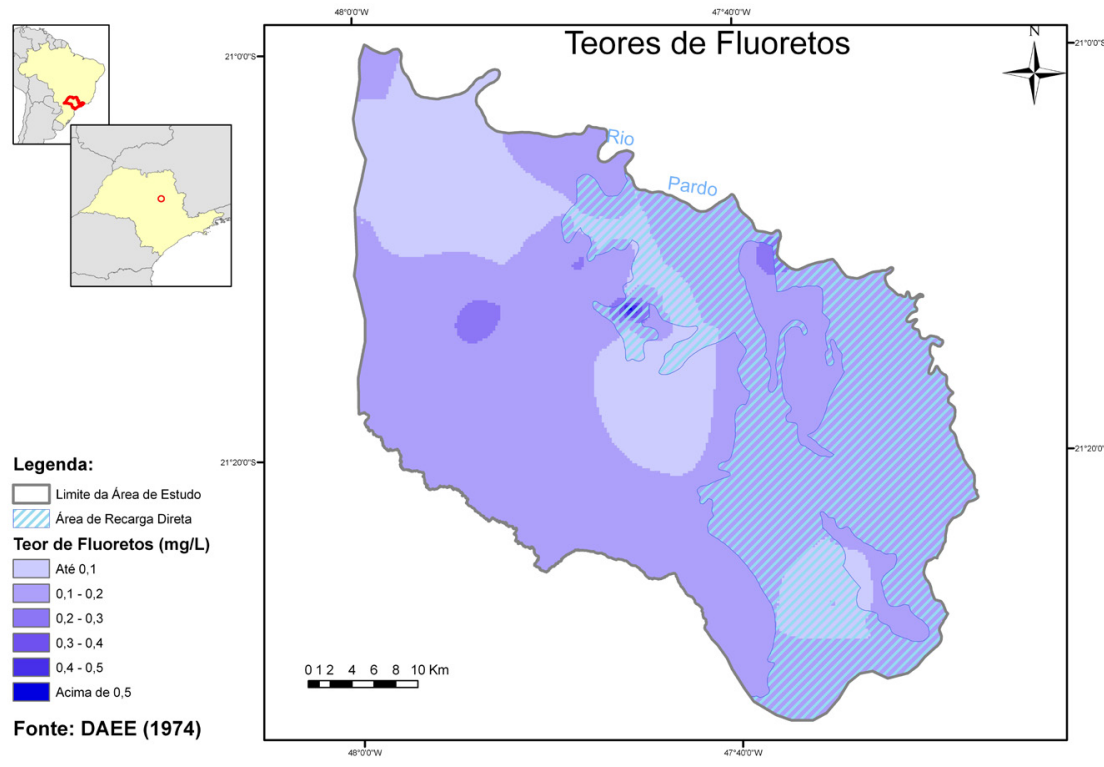

Figura 13. Mapa de isovalores do teor de fluoreto em $\mathrm{mg} / \mathrm{l}$ e poços amostrados, a partir dos dados do DAEE (1974).

Porém, algum tempo depois em contato com o ar pode se turvar e, mais tarde, produzir um depósito ferruginoso. Esse teor de ferro é de considerável interesse porque, mesmo pequenas quantidades, afetam sua utilização para algumas finalidades domésticas e industriais.

A Figura 14 mostra a distribuição dos teores de ferro das águas subterrâneas na área urbana de Ribeirão Preto. Nota-se que para o setor Norte do município as águas subterrâneas necessitam de correção com relação a esse parâmetro. Segundo Logan (1965) algumas indústrias precisam ter esses teores abaixo de $0,5 \mathrm{mg} / \mathrm{l}$ e suas águas necessitam de correção.

Para a irrigação, as principais restrições são águas de média a alta salinidade e com quantidade de sódio muito elevada. Estas águas restringem-se a certas áreas do Aquífero Guarani (setores mais confinados no Oeste do Estado), devendo ser analisado o grau de tolerância de determinadas culturas a estes componentes.

Já os requisitos de qualidade das águas utilizadas em diferentes processos industriais são muito variados. Há uma gama de especificações exigidas e critérios estabelecidos por tipos de indústrias e muitas vezes, uma pequena faixa de tolerância. Os parâmetros mais críticos e as maiores restrições são quanto à utilização em frigoríficos, cervejarias, curtumes, tecelagens e enlatamento de alimentos.

A imagem da boa cerveja está intimamente relacionada com a água que a produz. Apesar de no território brasileiro termos boas cervejas produzidas com águas tratadas de captações de rios, muitas das indústrias cervejeiras são supridas com águas subterrâneas (e o Aquífero Guarani é um desses reservatórios subterrâneos) por meio de poços profundos. Os padrões de tolerância para essas águas são vários. Às vezes, os parâmetros como alcalinidade, acidez, teor salino e os conteúdos de cálcio, ferro e flúor encontrados em excesso nas águas subterrâneas necessitam de correção durante o processo industrial da bebida. Por exemplo, os teores de dureza (representados pelos conteúdos de cálcio e magnésio nas águas) podem estar na faixa entre 50 e $135 \mathrm{mg} / \mathrm{l}$ para a indústria dos curtumes, até $20 \mathrm{mg} / \mathrm{l}$ para a indústria têxtil e entre 25 e $75 \mathrm{mg} / \mathrm{l}$ para a indústria de enlatamento
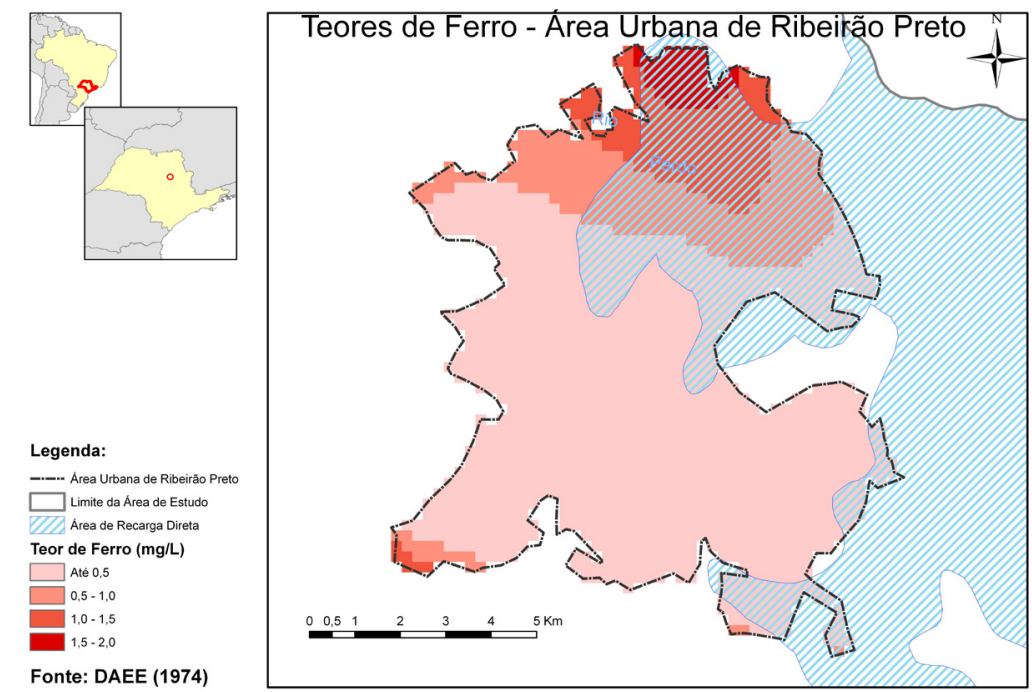

Figura 14. Mapa de isovalores do teor de ferro em $\mathrm{mg} / \mathrm{l}$ e poços amostrados, a partir dos dados do DAEE (1974). 
de vegetais.

As Figuras 15 e 16 mostram a distribuição dos teores de dureza na área de estudo e evidenciam que as concentrações nas águas subterrâneas na área, com relação a esse parâmetro, estão dentro do limite de tolerância.

\section{A relação das águas subterrâneas com usos antrópicos}

A contaminação dos solos e da água por elementos, compostos ou organismos que possam prejudicar a saúde do homem ou de animais podem ocorrer tanto no meio urbano ou rural e são umas das grandes preocupações do mundo moderno. Quando a contaminação não tem a origem natural que é provocada por constituintes dissolvidos de minerais constituintes das rochas e dos solos, ela é proveniente de atividades humanas e acabam atingindo os mananciais superficiais e subterrâneos.

A caracterização hidrogeológica, com a definição do tipo do aquífero e sua situação com relação ao modelo da recarga e da descarga do reservatório subterrâneo, é o primeiro passo para o estudo de uma área contaminada. Em seguida, o entendimento da composição química natural da água subterrânea natural e do histórico da contaminação (tempo, modo de disposição e definição dos contaminantes) e o estabelecimento de estratégias de

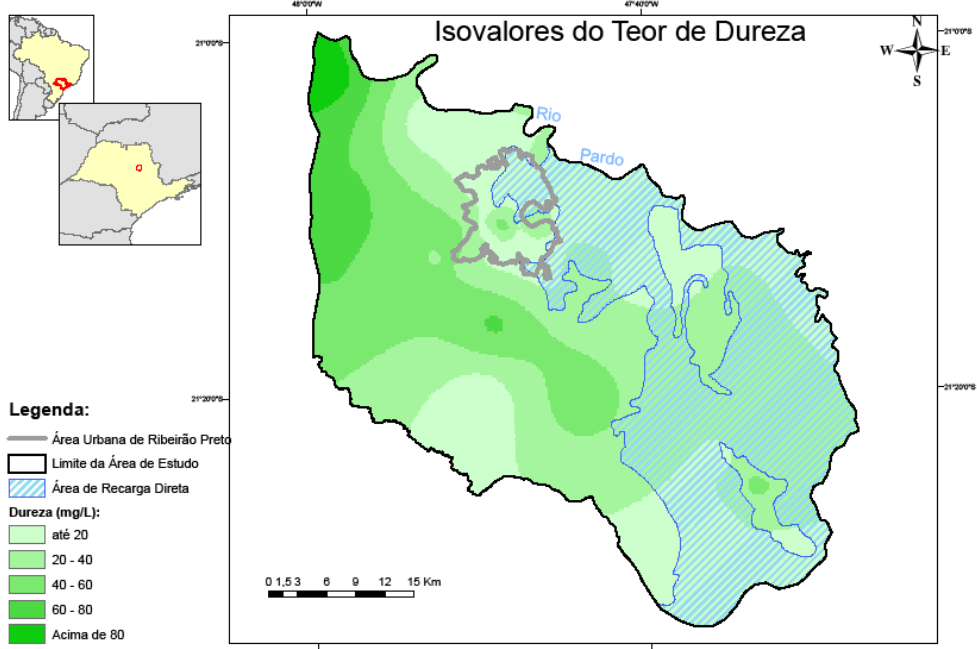

Figura 15. Mapa de isốvalores do teor de durêză em $\mathrm{mg} / \mathrm{l}$ e poços amostrados. Região de Ribeirão Preto, a partir de dados do DAEE (1974).
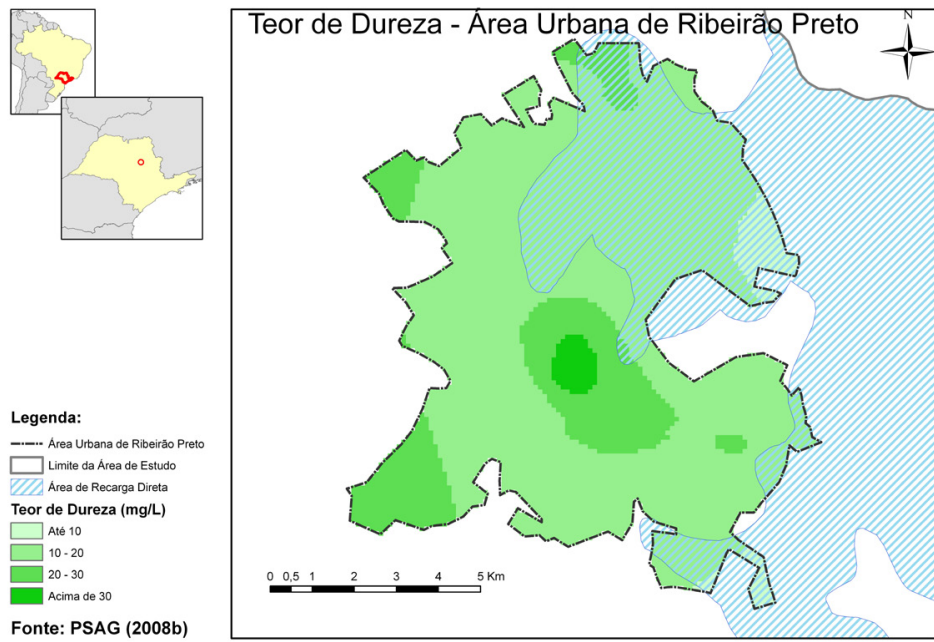

Figura 16. Mapa de isovalores do teor de dureza em mg/l e poços amostrados. Área urbana de Ribeirão Preto, a partir dos dados do PSAG (2008b). monitoramento (definição dos elementos a serem analisados, amostragens em corpos de água, obras de captação já existentes), são passos importantes na compreensão do problema.

O tratamento de um aquífero contaminado é bastante complexo e uma das formas para tentar trazê-lo mais próximo das condições naturais é por meio de remediação, que consiste em retirar ou atenuar a concentração do contaminante do solo ou da água subterrânea. Ela é feita com o emprego de diversos métodos de engenharia, para que a concentração seja reduzida a limites pré-determinados na avaliação de risco da saúde humana, apoiado na legislação vigente.

Os métodos de remediação podem incluir várias etapas. A escavação, a remoção e a destinação do solo; o bombeamento e o tratamento das águas subterrâneas; a extração de vapores do solo; a construção de barreiras reativas permeáveis; a oxidação química e a redução química in-situ e a biorremediação, entre outras. A biorremediação é uma técnica que se baseia na utilização de microorganismos na degradação de contaminantes existentes no solo e na água subterrânea. Os microorganismos podem ser adicionados ao meio ou estimulados ao crescimento por meio de adição de nutrientes.

A região de Ribeirão Preto vem sendo estudada há décadas por especialistas em águas subterrâneas por causa do Aquífero Guarani. Na região ocorre bem conhecido processo de expansão urbana e da atividade agrícola suportada no plantio da cana de 
açúcar. Como consequência, desenvolveu-se um uso descontrolado da água subterrânea, ao mesmo tempo em que se aumentou o risco de contaminação das águas principalmente pelo uso de agrotóxicos nas áreas de afloramento do aquífero (Zona Leste).

No Estado de São Paulo existe legislação específica sobre águas subterrâneas assim como legislação sobre recursos hídricos. Grosso modo, a base legal é discriminada em várias leis e decretos, cujo conteúdo dispõe sobre: (1) a preservação dos depósitos naturais de águas subterrâneas; (2) a defesa da qualidade e da quantidade; (3) a classificação das áreas de proteção; (4) a fiscalização e as penalidades; (5) a outorga de direitos de uso dos recursos hídricos e (6) o controle de poluição do meio ambiente.

Em outras palavras isso quer dizer que no âmbito do território estadual paulista as águas subterrâneas já têm um arcabouço jurídico para a sua gestão e governança. Na esfera dos municípios da região o que deve ser feito é a elaboração e a implementação de dispositivos legais. Estes dispositivos são as emendas aos planos diretores municipais que contemplem as áreas de proteção do Aquífero Guarani associados à adoção de medidas disciplinatórias de utilização das águas. Essas medidas de natureza legal são de médio prazo e devem ser lastreadas nos estudos técnicos já realizados na área.

Com a publicação no Diário Oficial do Estado de São Paulo da Resolução SMA-14, de 06/03/2010, da Secretaria de Estado do Meio Ambiente, que define as diretrizes técnicas para licenciamento de empreendimentos em áreas potencialmente críticas para a utilização de água subterrânea, importante passo foi dado para a gestão e proteção das águas subterrâneas no Estado de São Paulo e em Ribeirão Preto, particularmente, por causa do Aquífero Guarani. O Artigo $3^{\circ}$ da resolução afirma que:

(...) nas áreas de alta vulnerabilidade das águas subterrâneas não serão permitidas a implantação de indústrias de alto risco ambiental, pólos petroquímicos, carboquímicos e cloroquímicos, usinas nucleares e quaisquer outras fontes de grande impacto ambiental ou de extrema periculosidade, conforme determinado pelo artigo 21 do Decreto Estadual 32.955, de 07/02/1991.

Outro passo importante refere-se aos estudos e medidas de proteção para a Zona Leste de Ribeirão Preto, área de recarga direta do Aquífero Guarani (e de alta vulnerabilidade), sempre muito visada também pela especulação imobiliária. As medidas somente ganharão força se forem transformadas em lei municipal. É por essa área que a água de chuva se infiltra e abastece o manancial subterrâneo. Funciona como grande esponja que absorve a água e alimenta o aquífero. Se houver mais impermeabilização do solo na área já parcialmente ocupada, a infiltração diminuirá. A aparente solução com a ocupação vertical não contabiliza o aumento do tráfego de veículos, a carga de esgoto doméstico e, principalmente, uma demanda de água muito maior.

A Zona Leste é estratégica e deve ser considerada sob o ponto de vista de uma área de proteção de manancial e necessariamente tem que ter vegetação. É ideal nesse setor que predomine uma vegetação robusta e de porte, pois pelo tronco das árvores ocorre a penetração da água no subsolo. Além disso, as copas das árvores desempenham o importante papel de anteparo do impacto das águas de chuva, prevenindo a erosão do solo. A reconstituição da mata natural seria um primeiro passo nessa direção.

As medidas para o disciplinamento e o controle da retirada das águas do Aquífero Guarani em Ribeirão Preto e região vêm sendo discutidas no Comitê da Bacia Hidrográfica do Rio Pardo. Uma das ações que levam à gestão local é, por exemplo, não permitir novas perfurações de poços, a não ser para substituição de poços do abastecimento público, na zona central da cidade. Um primeiro passo dado nessa direção resultou na elaboração dos Critérios para Autorização de Perfuração de Poços Município de Ribeirão Preto 2005-2006 que o Conselho Estadual de Recursos Hídricos (CRH) homologou em 04/09/2006, na Deliberação CBH-Pardo 4/06. A Figura 17 mostra o zoneamento do município de Ribeirão Preto em função da Deliberação.

Estudos realizados há alguns anos no Estado de São Paulo já despertavam preocupação com áreas mais críticas e frágeis do Aquífero Guarani e que merecem políticas específicas de controle e manejo da ocupação do solo. A Zona Leste é uma área frágil, mas em contrapartida, por suas características naturais (rochas e relevo) é também uma área que possui beleza cênica peculiar. As cuestas basálticas, visíveis tanto da Estrada do Piripau como de vários pontos da rodovia Anhanguera, reúnem atributos que favorecem a criação de um parque (Fig. 18).

O parque, como em outras partes do mundo, seria aberto à visitação pública e poderia integrar futuramente a Rede de Geoparques da Unesco (Organização das Nações Unidas para a Educação, a Ciência e a Cultura). Existem 38 parques com esses 


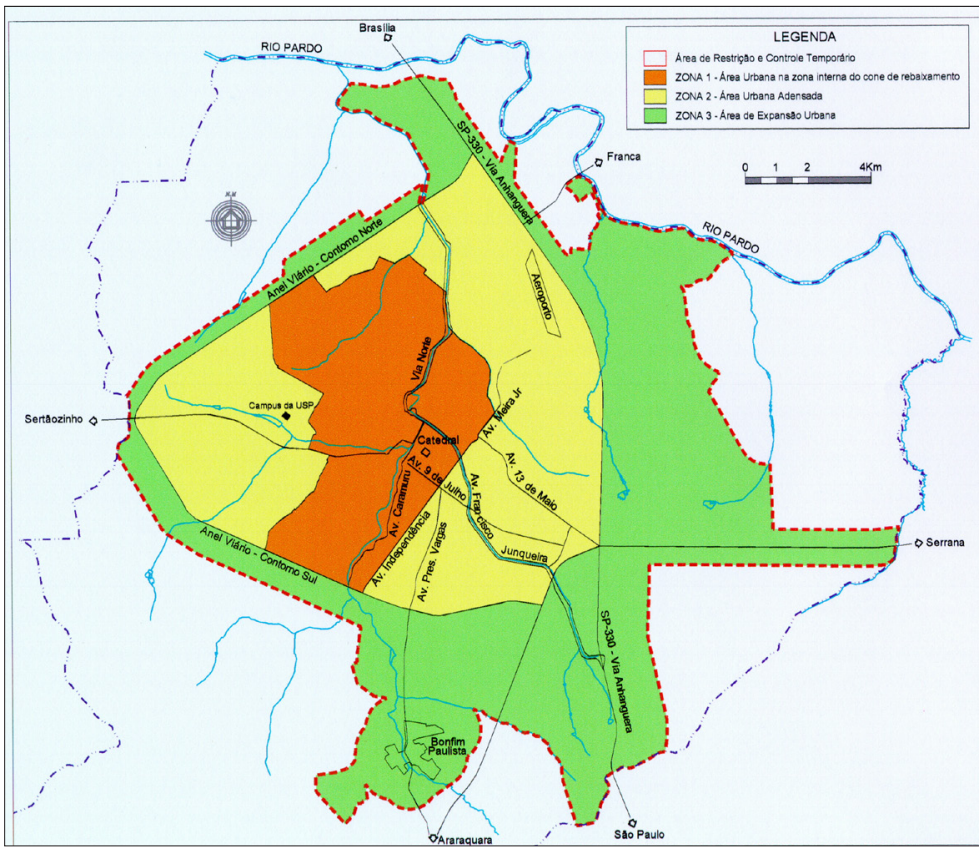

Figura 17. Zoneamento de áreas de restrição e controle temporário, conforme a Deliberação CBH-Pardo 4/06.

atributos no mundo. A maior concentração está na Europa que possui 25 parques, seguido da China com 12. Na América do Sul somente o Geoparque Araripe, localizado na divisa entre os Estados do Ceará, Piauí e Pernambuco integra a rede.

Assim, pelo exposto, a criação de um parque público, que reúna a proteção de manancial (Aquífero Guarani) e uma área de lazer na região, é uma necessidade para garantir o abastecimento de água para as atuais e futuras gerações.

\section{Considerações finais}

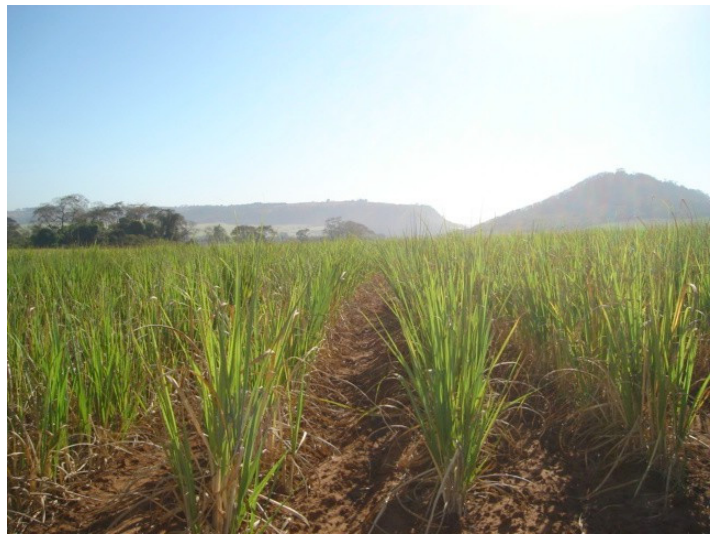

Figura 18. Estrada do Piripau, área de recarga direta sobre os arenitos Botucatu (Aquífero Guarani). Zona Leste do município de Ribeirão Preto (SP). Zona rural plantação de cana. Ao fundo, o relevo de cuestas basálticas.

\section{A qualidade das águas subterrâneas e as estratégias de proteção}

As estratégias de proteção da água subterrânea podem ter dois enfoques. O primeiro enfoque é a proteção pontual, voltada a uma captação de água subterrânea, em especial àquelas destinadas ao abastecimento humano. O segundo é a proteção geral de um aquífero importante, identificando áreas mais suscetíveis de forma a promover um controle regional do processo de uso do solo em toda a sua extensão.

Nestas áreas de proteção, a extração de água subterrânea está condicionada à recarga natural dos aquíferos e seu estabelecimento tem como referência estudos hidrogeológicos.

Um desses estudos é o projeto "Mapeamento de Vulnerabilidade e Risco de Poluição das Águas Subterrâneas do Estado de São Paulo" (IG et al. 1997) que identificou as áreas mais críticas no Estado de São Paulo as quais merecem políticas específicas de controle da ocupação do solo e de extração da água subterrânea. Uma destas áreas identificadas é a área de recarga do Aquífero Guarani.

Por outro lado, no âmbito das atribuições Federais, podem ser citadas a Lei no 9433 (08.01.1997) que institui a Política Nacional de Recursos Hídricos e as Resoluções do Conselho Nacional de Recursos Hídricos CNRH n ${ }^{\circ} 15$ (11.01.2001) e n ${ }^{\circ}$ 22 (24.05.2005), que estabelecem que os planos de recursos hídricos devam propor a criação de áreas de proteção dos recursos hídricos.

No Estado de São Paulo, as áreas de proteção das águas subterrâneas são definidas no Decreto $\mathrm{n}^{\mathrm{o}} 32.955$ (07/02/1991), que regulamenta a Lei $\mathrm{n}^{\circ}$ 6.134 (02/06/1988), a qual dispõe sobre a "preservação dos depósitos naturais de águas subterrâneas do Estado de São Paulo". Segundo o Decreto,

(...) sempre que, no interesse da conservação, proteção e manutenção do equilíbrio natural das águas subterrâneas, dos serviços de abastecimento de água, ou por motivos geotécnicos ou geológicos, se fizer necessário restringir a captação e o uso dessas águas, o Departamento de Águas e Energia Elétrica (DAEE) e a Companhia de Tecnologia de Sanea- 
mento Ambiental (Cetesb) proporão ao Conselho Estadual de Recursos Hídricos (CRH) a delimitação de áreas destinadas ao seu controle.

Assim, devido à importância do Aquífero Guarani no contexto de uma área de proteção das águas subterrâneas considera-se:

- Aquífero Guarani - um dos principais mananciais subterrâneos da bacia, é composto pelos sedimentos arenosos das formações Pirambóia e Botucatu; na sua área de ocorrência, parte da unidade aquífera é confinada pelos derrames basálticos do Aquífero Serra Geral;

- Vulnerabilidade - a vulnerabilidade (V) de um aquífero significa sua maior ou menor suscetibilidade de ser afetado por uma carga contaminante e envolve três fatores: a) ocorrência das águas subterrâneas (tipo do aquífero: livre, semiconfinado ou confinado), b) tipos litológicos acima da zona saturada do aquífero e c) profundidade das águas subterrâneas;

- $\quad$ Potencial de Contaminação (P) - é a carga potencial contaminadora que depende da: a) classe de contaminantes, b) intensidade do evento (concentração), c) modo de disposição e d) duração de aplicação;

- $\quad$ Risco de Contaminação (R) - é dada pela equação $\mathrm{R}=\mathrm{V} \times \mathrm{P}$;

- Área de Recarga - área de afloramento do Aquífero Guarani na qual estão expostas em superfície as rochas sedimentares das Formações Botucatu e/ou Pirambóia e solos derivados destas e área de afloramento dos basaltos que recobrem o Aquífero Guarani e que podem estar fraturados, numa faixa de $1 \mathrm{~km}$ a partir desse contato geológico; é uma área que requer maior preocupação ambiental comparando a sua alta vulnerabilidade e a sua carga potencial contaminante;

- Área de Proteção - área de conservação contra dano, perda ou desperdício do Aquífero Guarani;

- Área de Proteção Máxima - compreendendo, no todo ou em parte, zonas de recarga de aquíferos altamente vulneráveis à poluição e que se constituam em depósitos de águas essenciais para abastecimento público.

\section{Área de Proteção Máxima do Aquífero Guarani}

A área de afloramento do Aquífero Guarani tem papel fundamental na recarga deste recurso, devendo haver um controle do uso do solo para garantir a manutenção da qualidade da água subterrânea. Dessa maneira, três importantes características apresentadas por este reservatório permitem enquadrá-lo na categoria de Área de Proteção Máxima, segundo o artigo n ${ }^{\circ} 20$ do Decreto Estadual $n^{\circ}$ 32.955/91, pois:

- representa a área mais significativa de recarga do Aquífero Guarani, considerado um dos principais mananciais subterrâneos do Estado de São Paulo;

- apresenta alta vulnerabilidade natural à poluição devido a seu comportamento hidráulico de aquífero livre, com alta permeabilidade, como identificado no "Mapa de Vulnerabilidade das Águas Subterrâneas do Estado de São Paulo" (IG et al. 1997);

- é essencial para o abastecimento público, tendo como principal exemplo, o município de Ribeirão Preto, totalmente abastecido por este recurso hídrico subterrâneo.

\section{Medidas de proteção}

De acordo com a Constituição do Estado de São Paulo, artigo 210,

"para proteger e conservar as águas e prevenir seus efeitos adversos, o Estado incentivará a adoção, pelos Municípios, de medidas no sentido: I - da instituição de áreas de preservação das águas utilizáveis para abastecimento às populações e da implantação, conservação e recuperação de matas ciliares".

Para proteger a qualidade da água subterrânea do Aquífero Guarani algumas medidas visando sua proteção devem ser seguidas:

- todas as fontes potenciais de poluição existentes devem realizar uma investigação preliminar para avaliar a existência de passivo ambiental e, caso seja constatada alguma alteração, deve seguir os procedimentos do "Sistema de Gerenciamento de Áreas Contaminadas" definidos pela Cetesb;

- todos as atividades que já possuam o licenciamento ambiental, com exceção daquelas 
já proibidas de serem instaladas de acordo com o Decreto n ${ }^{\circ} 32.955 / 91$, devem realizar um estudo hidrogeológico detalhado, com definição de medidas de proteção a serem adotadas;

- todas as atividades que se constituam fontes potenciais de poluição já existentes, devem implantar um sistema de detecção de vazamento dos equipamentos e uma rede de poços de monitoramento de água para identificar qualquer alteração da qualidade da água; a frequência do monitoramento deve ser definida em consonância com o órgão ambiental responsável;

- o armazenamento e aplicação de qualquer efluente no solo somente serão permitidos se forem realizados de acordo com os critérios estabelecidos pelo órgão ambiental; as lagoas de armazenamento devem ser impermeabilizadas e possuir dreno testemunho;

- não é permitida a infiltração de efluentes domiciliares no solo; a rede de coleta de esgotos existente deve ter dispositivos para detecção de vazamentos.

Para efetivar a proteção das águas subterrâneas do Aquífero Guarani devem ser definidas restrições às atividades antrópicas e medidas de controle das fontes potenciais de poluição. De acordo com o artigo no 21, na Área de Proteção Máxima não são permitidos:

- a implantação de indústrias de alto risco ambiental, pólos petroquímicos, carboquímicos e cloroquímicos, usinas nucleares e quaisquer outras fontes de grande impacto ambiental ou de extrema periculosidade;

- as atividades agrícolas que utilizem produtos tóxicos de grande mobilidade e que possam colocar em risco as águas subterrâneas, conforme relação divulgada pela Cetesb e Secretaria de Agricultura e Abastecimento;

- o parcelamento do solo urbano sem sistema adequado de tratamento de efluente ou disposição de resíduos sólidos.

Ainda na Área de Proteção Máxima, definida neste decreto, em casos de escassez de água subterrânea ou de prejuízo sensível aos aproveitamentos existentes, o artigo 22 permite que o DAEE e a Cetesb possam:

- proibir novas captações até que o aquífero se recupere ou seja superado o fato que determinou a carência de água;

- restringir e regular a captação de água sub- terrânea, estabelecendo o volume máximo a ser extraído e o regime de operação;

- controlar as fontes de poluição existentes, mediante programa específico de monitoramento;

- restringir novas atividades potencialmente poluidoras.

Vale ressaltar que na Área de Proteção Máxima não deve ser permitida a eliminação de cobertura vegetal natural e devem ser preservadas as áreas de mata ciliar, em função do bem conhecido papel da cobertura vegetal natural no combate à erosão do solo e recarga do aquífero.

\section{Agradecimentos}

O autor agradece o apoio financeiro do Conselho Nacional de Desenvolvimento Científico e Tecnológico (CNPq) dado ao projeto de pesquisa de pós-doutoramento (Processo CNPq 150140/2009-6), sob a supervisão do Prof. Dr. Edson Cézar Wendland, realizado no período de 06/2009 a 05/2010 junto ao Departamento de Hidráulica e Saneamento da Escola de Engenharia de São Carlos, Universidade de São Paulo.

\section{Referências Bibliográficas}

ArcGIS. 2009. Geographic Information System Software. Environmental Systems Research Institute, Inc. (ESRI), Redlands, California, USA. URL: http:// www.esri.com.

Bonotto, D.M. 2006. Hydro(radio)chemical relationships in the giant Guarani aquifer, Brazil. Journal of Hydrology, 323:353-386.

Campos H.C.N.S. e Cerón-Garcia, J.C. 1998. Algunos aspectos de la hidroquímica del sistema acuífero Botucatu (Cuenca del Paraná, Estado de São Paulo, Brasil). Sociedad Geológica de España, Revista Geogaceta, 23:23-25.

Campos H.C.N.S. 1987. Contribuição ao estudo hidrogeoquímico do Grupo Bauru no Estado de São Paulo. São Paulo: Inst. Geoc., USP. 160p. (Dissert. Mestrado).

Campos H.C.N.S. 1993. Caracterização e cartografia das províncias hidrogeoquímicas do Estado de São Paulo. 1 mapa na escala 1:1.000.000. São Paulo: Inst. Geoc., USP. 177p. (Tese Dout.).

Campos H.C.N.S. 2000 a. Mapa hidrogeológico do Aqüífero Guarani. São Leopoldo: Acta Geologica Leopoldensia. 4. Anexo.

Campos H.C.N.S. 2000 b. Modelación conceptual y matemática del Acuífero Guaraní, CONO SUR. São Leopoldo: Acta Geologica Leopoldensia. 4:3-50. 
Campos H.C.N.S. 2003. Termos de Referência Para o Apoio Técnico ao Projeto Piloto Ribeirão Preto (São Paulo, Brasil). Projeto Proteção Ambiental e Desenvolvimento Sustentável do Sistema Aqüifero Guarani. Argentina-Brasil-Paraguai-Uruguai. GEF/ BIRF/OEA. (Rel. Final). URL: http://www.sg-guarani.org.

Cavicchia M.E. 2007. Desenvolvimento de modelo numérico para gerenciamento de recursos hídricos subterrâneos na área do Projeto Piloto Ribeirão Preto. São Carlos: Esc. Eng. São Carlos, USP. 169 p. (Dissert. Mestrado).

DAEE (Departamento de Águas e Energia Elétrica). 1974. Estudo de águas subterrâneas da região administrativa 6 (Ribeirão Preto). São Paulo: Geopesquisadora \& Tahal. 2v.

DAEE (Departamento de Águas e Energia Elétrica), IG (Instituto Geológico), IPT (Instituto de Pesquisas Tecnológicas), CPRM (Serviço Geológico do Brasil). 2005. Mapa de Águas Subterrâneas do Estado de São Paulo. São Paulo: DAEE. (3v, mapa e CD-ROM).

FIPAI (Fundação Para o Incremento da Pesquisa e Aperfeiçoamento Industrial). 2009. Desenvolvimento de modelo numérico para gerenciamento de recursos hídricos subterrâneos na área do Projeto Piloto de Ribeirão Preto. Relatório 2, Etapa: Elaboração do modelo conceitual. Características hidrogeológicas regionais, modelo conceitual preliminar e modelo numérico. Projeto 2007-Pardo-135 SECOFEHIDRO 322/2007.

Gallo G., Sinelli O. 1980. Estudo hidroquímico e isotópico das águas subterrâneas de Ribeirão Preto (SP). Rev. Bras. Geoc., 10(2):129-140.

Gallo G. 1977. Utilization complementaire de l'hydrochimie et de la geochimie isotopique em hydrogeologie: application aux eaux souterraines de la region de Ribeirão Preto, état de São Paulo, Brésil. Lyon: Univ. Claude Bernard. (Thése Dipl. Doucter de $3^{\text {éme }}$ Cycle).

Gastmans D., Veroslavsky, G., Kiang Chang, H., Caetano-Chang, M.R., Pressinotti, M.M.N. 2012. Modelo hidrogeológico conceptual del Sistema Acuífero Guaraní (SAG): una herramienta para la gestión. Boletín Geológico y Minero, 123(3):249-265.
IG (Instituto Geológico), Cetesb (Companhia de Tecnologia de Saneamento Ambiental), DAEE (Departamento de Águas e Energia Elétrica). 1997. Mapa de Vulnerabilidade e de Risco de Poluição das Águas Subterrâneas no Estado de São Paulo. São Paulo, IG/Cetesb/IPT. 2 vol.

Invernizzi A.L. 2001. Caracterização hidrogeoquímica do Aquífero Botucatu, no setor médio da Bacia Hidrográfica Mogi-Pardo. São Paulo: Inst. Geoc., USP. 103p. (Dissert. Mestrado).

Logan J. 1965. Interpretação de análises químicas de água. Recife: U.S. Agency for International Development. 75p.

Massoli M. 2007. Caracterização litofaciológica das formações Pirambóia e Botucatu, em subsuperfície, no município de Ribeirão Preto (SP), e sua aplicação na pospecção de águas subterrâneas. 174 p. Rio Claro: Inst. Geoc. Ciênc. Exatas, Univ. Est. Paulista. (Tese Dout.).

Paula e Silva F., Kiang Chang H., Caetano-Chang M.R., Sinelli O. 2008. Arcabouço geológico e hidrofácies do Sistema Aquífero Guarani, no município de Ribeirão Preto (SP). Rev. Bras. Geoc., 38(1):56-67.

PSAG (Proyecto para la Protección Ambiental y Desarrollo Sostenible del Sistema Acuífero Guarani). 2008b. Hidrogeologia del área Piloto Ribeirão Preto. Sistema Acuifero Guarani. Contrato No. LPI/03/05. Servicios de Inventario, Muestreo, Geología, Geofísica, Hidrogeoquímica, Isótopos e Hidrogeología Localizada de las Áreas Operativas Norte y Sur del Sistema Acuífero Guarani. Montevidéu: OEA. (mayo 2008).

Silva R.B.G.S. 1983. Estudo hidroquímico e isotópico das águas subterrâneas do aqüifero Botucatu no Estado de São Paulo. São Paulo: Inst. Geoc., USP. 133p. (Tese Dout.).

Souza W.V.V., Campos H.C.N.S. 1993. Sistema de informações químicas de águas subterrâneas-SIQUIM. In: Simpósio Sul-Brasileiro de Geologia, 5, Curitiba: SBG-Núcleo Paraná.

Golden Software Inc., 2009. Surfer (Surface Mapping System). Colorado, USA. URL: http://www.goldensoftware.com. 